•研究报告・

\title{
新疆准噶尔山楂不同居群的遗传多样性
}

\author{
盛 芳 ${ }^{1}$ 陈淑英 ${ }^{2}$ 田 嘉 ${ }^{*}$ 李 鹏 ${ }^{1}$ 秦 雪 ${ }^{1}$ 罗淑萍 ${ }^{1}$ 李 疆 $^{{ }^{*}}$ \\ 1 (新疆农业大学, 乌鲁木齐 830052) \\ 2 (新疆伊犁州林业科学研究院, 新疆伊宁 835000 )
}

\begin{abstract}
摘要: 为了揭示新疆准噶尔山楂(Crataegus songorica) 不同居群的遗传多样性, 为其合理保护与利用提供科学依 据, 采用表型性状变异分析和SSR分子标记相结合的方法, 对新疆霍城大西沟准噶尔山楂的 5 个不同居群的 92 个个 体进行遗传多样性分析。结果表明: (1) 33 个表型性状的变异系数在2.96-71.32\%之间, 表型性状之间存在着丰富的 变异。居群间的平均表型分化系数为 $13.90 \%$, 而居群内的平均表型分化系数为 $86.10 \%$, 表明新疆准噶尔山楂居群 内的变异是其表型变异的主要来源。(2) 43对SSR引物共检测到739个位点, 物种水平上多态性位点比率为 $90.53 \%$, Nei's多样性指数和Shannon多样性指数 $(I)$ 分别为 0.2377 和 0.3712 , 居群内基因多样度 $\left(H_{s}\right)$ 为 0.1635 , 总居群基因多 样度 $\left(H_{t}\right)$ 为 0.2023 , 居群间遗传分化系数 $\left(G_{s t}\right)$ 为 0.1916 , 基因流 $\left(N_{m}\right)$ 为 2.1116 。新疆准噶尔山楂总的遗传多样性水平 较高, 居群间遗传分化较小。UPGMA聚类结果显示 5 个居群形成 2 个亚类, 不同居群所处的生境的不同是引起居群 间差异的主要原因。研究表明, 新疆准噶尔山楂不同居群在表型和分子水平均具有较高的遗传多样性, 居群内的 遗传分化较大，并且分化趋势具有地域性，因此可以选择就地保护。
\end{abstract}

关键词: Crataegus songorica; SSR; 表型性状; 遗传变异

\section{Genetic diversity of Crataegus songorica in Xinjiang}

Fang Sheng ${ }^{1}$, Shuying Chen ${ }^{2}$, Jia Tian ${ }^{1 *}$, Peng $\mathrm{Li}^{1}$, Xue Qin ${ }^{1}$, Shuping Luo ${ }^{1}$, Jiang $\mathrm{Li}^{1 *}$

1 Xinjiang Agricultural University, Urumqi 830052

2 Academy of Forestry in Ili, Yining, Xinjiang 835000

\begin{abstract}
The aim of this study is to reveal the genetic diversity of different populations of Crataegus songorica and to provide a scientific basis for its protection and sustainable utilization. The experimental materials included 92 samples, which were selected from Daxigou, Huocheng County in Xinjiang and analyzed by combining the analysis of phenotypic trait variation and the SSR marker. Results showed that there was considerable genetic variation in the phenotypic traits of different $C$. songorica populations, as the variation coefficient varied from $2.96 \%$ to $71.32 \%$, and the phenotypic variation was mainly caused by the variation within population, as the mean phenotypic differentiation coefficient was $13.90 \%$ among populations and $86.10 \%$ within population. A total of 739 loci were detected from five populations by 43 SSR primers, and the polymorphism loci ratio was $90.53 \%$ at the species level. Nei's diversity index, Shannon's diversity index $(I)$, the gene diversity within population $\left(H_{s}\right)$, the total population genetic diversity $\left(H_{t}\right)$, genetic differentiation coefficient and gene flow were $0.2377,0.3712,0.1635,0.2023,0.1916$ and 2.1116 , respectively. Comprehensive analysis suggested that the total genetic diversity of C. songorica was higher in Daxigou, and the genetic differentiation among populations was smaller. The results of UPGMA clustering showed that five populations formed two sub-types, and the differences in different habitats were the main causes of the discrepancy among populations. We conclude that the genetic diversity of $C$. songorica of different populations was high both at phenotypic and molecular levels in Daxigou, and there was a visible genetic differentiation within population, moreover differentiation trends had regional characteristics. Therefore, in situ conservation is supposed to be an effective method to protect $C$. songorica.
\end{abstract}

收稿日期: 2016-12-27; 接受日期: 2017-03-20

基金项目: 国家林业公益性行业科研专项课题(201304701-1)和新疆维吾尔自治区园艺学重点学科基金(2016-10758-3)

* 共同通讯作者 Co-authors for correspondence. E-mail: lijiangxj@163.com; terrisay@163.com 
Key words: Crataegus songorica; SSR; phenotypic traits; genetic diversity

山楂是蓄薇科山楂属(Crataegus)落叶乔木, 在 北半球广泛分布, 其中北美种类最多(赵焕谆和丰 宝田, 1996)。据记载, 中国分布有 18 个种 6 个变种(赵 焕谆和丰宝田, 1996)。在中国新疆阿勒泰、伊犁、 塔城、博乐、昌吉、乌鲁木齐河谷等地区分布有大 面积的野山楂种质资源，目前已鉴定的有 3 个种: 准噶尔山楂 (C. songorica)、阿尔泰山楂( C. chlorocarpa) 和红果山楂 (C. sanguinea)。这些野生资源不仅具有 很高的营养价值, 还可作栽培山楂的砧木和育种材 料, 利用价值极高。长期以来, 野山楂资源在我国 未得到足够重视, 另外由于人为活动的干扰, 其生 态环境遭到严重破坏, 野山楂资源正在逐渐消亡。 据调查, 天山野果林的实际分布面积只有 50 年前的 30\%左右 (尹林克, 2006), 而野山楂作为天山野果林 的主要组成树种之一, 其群落面积逐年递减, 大西 沟分布的野山楂主要是准噶尔山楂(赵焕谆和丰宝 田，1996), 在大西沟的各个沟均有分布, 分布数量 稍少于野杏(Armeniaca vulgaris)。近年来由于人畜 破坏、病虫害蔓延、景区开发等, 准噶尔山楂数量 不断减少。资源和遗传多样性的严重破坏, 易引起 基因匮乏和种群退化, 因此, 加强野山楂种质资源 的保护刻不容缓。

遗传多样性是资源保护与评价的重要指标，而 表型性状作为遗传多样性最直接的外观性状被广 泛应用(于万里和张博, 2012; 黄春琼等, 2012)。表 型变异是由遗传多样性和环境变异共同作用而成, 可在一定程度上反映物种的整体变异水平, 不但可 以揭示植物与环境之间的关系, 而且有助于认识植 物适应环境的机制、适应方式及其影响因素, 加强 对自然选择、基因流和遗传漂变的理解。目前, 表 型性状研究已被广泛应用于野生樱桃李(Prunus cerasifera) (刘崇琪等, 2008)、野苹果(Malus sieversii) (王昆等, 2008)、野生秋子梨(Pyrus ussuriensis) (安 萌萌等, 2014)、野杏(曹倩等, 2016)等野生果树种质 资源的研究中。

SSR 作为共显性分子标记技术，具有共显性 强、多态性高、稳定性和重复性好、实验操作简单、 快捷和易于分析等优点, 能够较好地满足种质资源 遗传多样性研究的要求(顾钱洪等, 2011), 同时SSR
可有效地避免环境因素的干扰。与其他分子标记相 比, SSR避免了AFLP标记的复杂性、RAPD标记的重 复性差和ISSR显性标记等缺点, 所以成为目前分子 标记中使用最多并且较为理想的标记方法, 已被广 泛地应用在野杏(包文泉等, 2016)、野苹果(董研等, 2013)、野生欧洲李(Prunus domestica) (耿文娟等, 2012)、野核桃(Juglans regia) (王肇延等, 2011)等野 生果树种质资源的研究中。相对而言, 野山楂的相 关研究以其果实色素提取(吕海英等, 2011)、形态特 征描述和花器官(刘欢等, 2014, 2015)的报道居多, 在分子水平上，只有刘欢等(2016)用ISSR分析了新 疆野山楂不同品种之间的遗传多样性和亲缘关系, 关于野山楂表型多样性的研究及SSR标记的研究尚 未见报道。

本研究从新疆准噶尔山楂形态特征和遗传变 异出发, 以海拔高度为分类依据, 在霍城大西沟共 采集92份种质资源作为研究材料, 利用分子标记和 植株表型性状的相关测定对其遗传多样性和遗传 结构进行分析, 以期为进一步研究其遗传多样性提 供科学依据。

\section{1 材料和方法}

\section{1 实验材料}

2015-2016年多次对新疆霍城县大西沟的准噶 尔山楂进行野外实地调查, 发现准噶尔山楂主要分 布在海拔1,000-1,500 m之间。按照不同的海拔高度 取样, 相邻样地相隔约 $100 \mathrm{~m}$ 的海拔高度, 每个采 样地作为 1 个居群处理, 共有 5 个居群。选取每个居 群中生长正常、无病虫害的植株，每株之间相隔至 少 $50 \mathrm{~m}$, 共选取了92份种质。对所选定的植株进行 GPS定位并挂牌标记。同时采集幼叶，硅胶干燥后 保存备用。各居群材料的采样地信息见表1。

\section{2 表型性状的测量}

在准噶尔山楂新梢基本停止生长的6-7月，在 每个植株树冠的 4 个方位选取 5 片完好叶片, 用游标 卡尺测量叶片长、叶片宽、叶柄长、叶柄粗等指标, 用Win FOLIA测量叶片面积; 并从树冠的 4 个方位 选取一年生枝和新梢对其枝长进行测量和外部性 状记录。在果实成熟期，从已标号树体四围随机选 
表1 准噶尔山楂各居群采样地的地理信息及样本数

Table 1 Geographic information and sample size of Crataegus songorica in different populations

\begin{tabular}{lllll}
\hline 居群代码 Population & 北纬 Latitude $(\mathrm{N})$ & 东经 Longitude (E) & 海拔 Altitude $(\mathrm{m})$ & 样本数 Sample size \\
\hline Pop1 & $44^{\circ} 23^{\prime} 55.1^{\prime \prime}-44^{\circ} 24^{\prime} 73.0^{\prime \prime}$ & $80^{\circ} 45^{\prime} 81.6^{\prime \prime}-80^{\circ} 46^{\prime} 15.1^{\prime \prime}$ & $1,000-1,100$ & 14 \\
Pop2 & $44^{\circ} 23^{\prime} 45.5^{\prime \prime}-44^{\circ} 25^{\prime} 97.0^{\prime \prime}$ & $80^{\circ} 40^{\prime} 15.1^{\prime \prime}-80^{\circ} 46^{\prime} 65.7^{\prime \prime}$ & $1,100-1,200$ & 25 \\
Pop3 & $4^{\circ} 24^{\prime} 78.9^{\prime \prime}-44^{\circ} 26^{\prime} 25.2^{\prime \prime}$ & $80^{\circ} 45^{\prime} 57.1^{\prime \prime}-80^{\circ} 48^{\prime} 31.4^{\prime \prime}$ & $1,200-1,300$ & 24 \\
Pop4 & $44^{\circ} 25^{\prime} 86.6^{\prime \prime}-44^{\circ} 25^{\prime} 94.2^{\prime \prime}$ & $80^{\circ} 45^{\prime} 67.0^{\prime \prime}-80^{\circ} 46^{\prime} 06.5^{\prime \prime}$ & $1,300-1,400$ & 19 \\
Pop5 & $44^{\circ} 25^{\prime} 92.1^{\prime \prime}-44^{\circ} 26^{\prime} 17.6^{\prime \prime}$ & $80^{\circ} 45^{\prime} 78.9^{\prime \prime}-80^{\circ} 46^{\prime} 28.3^{\prime \prime}$ & $1,400-1,500$ & 10 \\
\hline
\end{tabular}

取果实样品 30 个, 测量其外形, 并观测记录果实品 质和外部形态。共观测形态指标 33 个, 观测标准参 照《山楂种质资源描述规范和数据标准》(吕德国和 李作轩, 2006)。

\section{3 表型性状的统计}

对非数值性状进行赋值, 计算每个样株各性状 的平均值, 利用 Excel 软件和 SPSS 中的 One-Way ANOVA程序对 5 个居群 92 个个体的表型性状进行 分析, 可得到每一性状的平均值、均方、标准差、 标准误差、方差、 $F$ 值和显著性水平。

表型分化系数 $\left(V_{S T}\right)$ 描述了性状居群间方差占 居群方差的比例, 可以反映居群间的表型分化状 况。参照葛颂等(1988)的方法, 计算公式为: $V_{S T}=$ $\left[\delta_{t / s}^{2}\right] /\left[\delta_{t / s}^{2}+\delta_{s}^{2}\right]$ 。其中 $\delta_{t / s}^{2}$ 为居群间方差分量, $\delta_{s}^{2}$ 为居群 内方差分量。变异系数 $(\mathrm{CV})$ 衡量表型性状的离散程 度, 反映表型的变异特征(王肇延等, 2011), $C V=$ $S / X$, 其中 $S$ 为标准差, $X$ 为平均值。相对极差 $\left(R_{i}{ }^{\prime}\right)$ 用来 表示性状的极端差异程度, $R_{i}{ }^{\prime}=R_{i} / R_{0}$, 其中 $R_{i}$ 表示 居群内的极差, $R_{0}$ 表示总极差。

\subsection{SSR标记分析}

采用改良的CTAB法提取植株总DNA，用 $1 \%$ 琼 脂糖凝胶进行DNA质量检测, 采用紫外分光光度计 测定DNA浓度, 将符合要求的DNA浓度稀释至 30-50 ng/ $\mu \mathrm{L}$ 并置于 $-20^{\circ} \mathrm{C}$ 冰箱保存备用。根据已报 道的蓄薇科植物(桃、杏、梅、梨、苹果)的SSR 引 物, 挑选出多态性高、重复性好的引物130对; 并从 NCBI 数据库中搜索苹果亚科的EST序列, 利用 EditPlus 3 和SSR Hunter 1.3进行EST-SSR位点的搜 寻, 用Primer 6.0设计91对引物, 由英潍捷基(上海) 贸易有限公司合成 221 对引物用于本研究。 $20 \mu \mathrm{L}$ PCR反应体系: $10 \times$ Buffer $\left(\right.$ 含 $\mathrm{Mg}^{2+}$ ) $2 \mu \mathrm{L}, 2.5 \mathrm{mM}$ dNTP $1.6 \mu \mathrm{L}, 10 \mathrm{mM}$ 引物各 $0.6 \mu \mathrm{L}, T a q D N A$ 聚合酶 $0.5 \mathrm{U}$, 模板DNA $50 \mathrm{ng}$, 在Biometra TProfessional Thermocycler上进行PCR扩增。PCR反应程序参照韩
志校等(2014)的山楂SSR反应程序: $94^{\circ} \mathrm{C} 5 \mathrm{~min} ; 95^{\circ} \mathrm{C}$ $50 \mathrm{~s}, \mathrm{Tm} \pm 2^{\circ} \mathrm{C} 50 \mathrm{~s}, 72^{\circ} \mathrm{C} 1 \mathrm{~min}, 30$ 个循环; $72^{\circ} \mathrm{C}$ $7 \mathrm{~min} ; 4^{\circ} \mathrm{C}$ 保存。扩增产物以 $8 \%$ 聚丙烯酰胺凝胶进 行电泳分离, 硝酸银染色、显影后用于拍照并进行 条带统计。

\subsection{SSR图谱数据分析}

统计PCR扩增图谱上清晰的SSR条带数据, 相 同迁移位点上有DNA条带的记为 1 , 无条带的记为 0 , 记录长度在 $50-450 \mathrm{bp}$ 范围内, 形成 $0 / 1$ 矩阵。数据矩 阵用POPGENE 1.32进行分析, 计算多态性位点比 率 $(P P B)$, 观察等位基因数 $\left(N_{a}\right)$, 有效等位基因数 $\left(N_{e}\right)$, Nei's 基因多样性指数 $(H)$, Shannon多样性指数 (I), 总居群基因多样度 $\left(H_{t}\right)$, 居群内基因多样度 $\left(H_{s}\right)$ 和遗传分化系数 $\left(G_{s t}\right)$ 。用NTSYS-pc 2.1软件进行居 群内UPGMA聚类分析。

\section{2 结果}

\section{1 各表型性状变异式样及变异特征}

表型变异系数 $(C V)$ 反映表型性状的离散程度: 变异系数越大, 表型性状离散程度越高, 则表型分 化越大。由表2可知, 33 个表型性状的平均变异系数 为 $19.69 \%$, 变异幅度为 $2.96-71.32 \%$, 表型性状变异 幅度较大, 各性状间分化较大。变异程度最大的是 果实形状 $(C V=71.32 \%)$, 最小的是果核数和果核纵 径 $(C V=2.96 \%)$, 说明果实形状在居群内的分化最 大, 果核数和果核纵径在居群内较稳定。

33 个表型性状在 5 个居群中的表现存在着一定 的差异，同一性状在不同居群中的变异程度也有很 大差异 (表 2 )。叶厚的变异系数在居群 5 中最大 (26.86\%), 在居群1中最小 $(15.41 \%)$; 单果重的变异 系数在居群 2 中最大 $(19.94 \%)$, 在居群 5 中最小 $(5.12 \%)$ 。这可能是由不同居群所处环境的差异导 致。同一居群中的不同性状的变异也存在很大差 别。如居群 1 中, 各性状的 $C V$ 变化幅度在 
$2.11-79.52 \%$ 之间，果实形状的变异系数 $(79.52 \%)$ 最 高, 果核纵径的变异系数 $(2.11 \%)$ 最低; 居群4中, 果 实形状变异系数 $(72.54 \%)$ 最大, 果核数变异系数 $(1.86 \%)$ 最小。可见每一居群的每一性状均存在丰富 的变异。

此外，枝条的 3 个性状(一年生枝长、一年生枝 粗、新稍长)平均变异系数 $(26.90 \%)>$ 果实的 12 个性 状(单果重、果实纵径、果实横径、果柄长、果柄粗、 坐果数、果实硬度、可固性、果实形状、果皮颜色、 果肉颜色、果实风味)平均变异系数 $(21.40 \%)>$ 叶片的 13 个性状(叶厚、叶面积、叶宽、叶长、叶形指数、 叶柄长、叶柄粗、叶柄指数、叶片颜色、叶基形态、
叶缘形态、叶面状态、托叶形状)平均变异系数 $(20.92 \%)>$ 果核的 4 个性状(果核数、鲜核重、果核纵 径、果核横径)的平均变异系数 $(5.03 \%)$, 说明准噶尔 山楂枝条、果实和叶片性状受环境影响变异较大, 果核性状相对遗传稳定性最高。

变异系数还可以间接反映居群表型多样性的 丰富程度: 变异系数大, 说明居群性状的变异幅 度较高，表型多样性丰富；反之，变异幅度较小， 表型多样性差。准噶尔山楂不同居群表型性状的平 均变异系数(表 2) 从大到小的顺序为: 居群 2 $(22.06 \%)>$ 居群3 $(20.90 \%)>$ 居群1 $(20.77 \%)>$ 居群4 $(19.92 \%)>$ 居群5 $(14.80 \%)$, 表明高海拔居群平均变

表2 准噶尔山楂各居群表型性状变异系数统计表

Table 2 Statistic $C V$ of phenotypic characteristics in Crataegus songorica populations

\begin{tabular}{|c|c|c|c|c|c|c|c|c|}
\hline \multirow[t]{2}{*}{ 表型性状 Phenotypic traits } & \multirow[t]{2}{*}{$\begin{array}{l}\text { 平均值 } \\
\text { Mean value }\end{array}$} & \multicolumn{5}{|c|}{$\begin{array}{l}\text { 变异系数 } \\
\text { Coefficient of variance (\%) }\end{array}$} & \multicolumn{2}{|c|}{$\begin{array}{l}\text { 居群平均值 } \\
\text { Average of population }\end{array}$} \\
\hline & & Pop1 & Pop2 & Pop3 & Pop4 & Pop5 & $\begin{array}{l}\text { 变异系数 } \\
\mathrm{CV}(\%)\end{array}$ & $\begin{array}{l}\text { 相对极差 } \\
R_{i}{ }^{\prime}\end{array}$ \\
\hline 一年生枝长 Annual branch length (mm) & 109.09 & 42.64 & 44.92 & 39.57 & 30.81 & 24.69 & 36.53 & 0.68 \\
\hline 一年生枝粗 Annual branch diameter (mm) & 3.52 & 14.96 & 16.27 & 24.10 & 9.61 & 10.81 & 15.15 & 0.52 \\
\hline 新梢长 New branch length (mm) & 178.99 & 23.99 & 34.87 & 40.43 & 29.13 & 16.63 & 29.01 & 0.59 \\
\hline 单果重 Fruit weight (g) & 0.93 & 11.60 & 19.94 & 13.99 & 17.34 & 5.12 & 13.60 & 0.54 \\
\hline 果实纵径 Fruit longitudinal diameter (mm) & 12.46 & 2.68 & 5.57 & 4.03 & 4.47 & 0.71 & 3.49 & 0.51 \\
\hline 果实横径 Fruit diameter (mm) & 11.38 & 5.98 & 8.97 & 6.05 & 6.23 & 1.96 & 5.84 & 0.52 \\
\hline 果柄长 Fruit stalk length (mm) & 11.02 & 9.85 & 17.01 & 11.85 & 6.14 & 13.77 & 11.72 & 0.47 \\
\hline 果柄粗 Fruit stalk thickness (mm) & 0.63 & 5.76 & 15.01 & 6.70 & 11.71 & 5.38 & 8.91 & 0.41 \\
\hline 坐果数 Fruit set number & 3.21 & 13.22 & 27.39 & 10.35 & 37.67 & 4.33 & 18.59 & 0.45 \\
\hline 果实硬度 Fruit hardness $\left(\mathrm{kg} / \mathrm{cm}^{2}\right)$ & 1.77 & 8.33 & 20.20 & 18.68 & 14.09 & 5.61 & 13.38 & 0.51 \\
\hline 可固性 Soluble solids (\%) & 15.18 & 11.75 & 19.18 & 13.56 & 9.25 & 4.72 & 11.69 & 0.50 \\
\hline 果实形状 Fruit shape & 3.36 & 79.52 & 68.12 & 68.27 & 72.54 & 68.12 & 71.32 & 0.45 \\
\hline 果皮颜色 Peel color & 5.87 & 21.34 & 29.41 & 30.25 & 24.98 & 22.22 & 25.64 & 0.67 \\
\hline 果肉颜色 Flesh color & 4.05 & 18.47 & 25.85 & 26.70 & 21.64 & 14.52 & 21.44 & 0.56 \\
\hline 果实风味 Fruit flavor & 2.08 & 50.25 & 50.22 & 47.67 & 57.57 & 50.25 & 51.19 & 0.56 \\
\hline 叶厚 Leaf thickness (mm) & 0.27 & 15.41 & 17.74 & 18.22 & 21.10 & 26.86 & 19.87 & 0.67 \\
\hline 叶面积 Leaf area $\left(\mathrm{cm}^{2}\right)$ & 15.48 & 24.29 & 22.54 & 21.38 & 19.10 & 13.72 & 20.20 & 0.60 \\
\hline 叶宽 Leaf width (cm) & 5.18 & 8.89 & 10.55 & 8.67 & 8.10 & 1.85 & 7.61 & 0.53 \\
\hline 叶长 Leaf length $(\mathrm{cm})$ & 5.48 & 13.22 & 10.93 & 11.20 & 8.31 & 1.69 & 9.07 & 0.60 \\
\hline 叶形指数 Leaf length/leaf width & 1.06 & 7.48 & 6.16 & 4.20 & 5.96 & 0.16 & 4.79 & 0.54 \\
\hline 叶柄长 Petiole length (mm) & 25.99 & 16.46 & 17.39 & 14.26 & 19.27 & 15.22 & 16.52 & 0.63 \\
\hline 叶柄粗 Petiole thickness (mm) & 1.14 & 32.05 & 15.19 & 16.82 & 13.06 & 7.64 & 16.95 & 0.62 \\
\hline 叶柄指数 Petiole length/petiole thickness & 23.65 & 32.62 & 25.83 & 25.49 & 28.11 & 22.73 & 26.96 & 0.71 \\
\hline 叶片颜色 Leaf color & 3.00 & 23.89 & 27.19 & 26.83 & 21.32 & 25.27 & 24.90 & 0.41 \\
\hline 叶基形态 Leaf base morphology & 2.82 & 55.17 & 35.88 & 36.93 & 41.57 & 47.02 & 43.31 & 0.62 \\
\hline 叶缘形态 Leaf margin morphology & 2.78 & 13.22 & 17.68 & 14.92 & 16.59 & 13.52 & 15.19 & 0.70 \\
\hline 叶面状态 Status of leaf surface & 1.29 & 50.25 & 41.61 & 52.36 & 43.86 & 34.26 & 44.47 & 0.59 \\
\hline 托叶形状 Stipule shape & 2.49 & 20.10 & 26.98 & 23.53 & 20.10 & 20.10 & 22.16 & 0.74 \\
\hline 果核数 Stone number & 1.99 & 2.24 & 3.74 & 4.07 & 1.86 & 2.89 & 2.96 & 0.48 \\
\hline 鲜核重 Fresh stone weight (g) & 0.24 & 9.25 & 10.88 & 13.52 & 13.29 & 2.61 & 9.91 & 0.55 \\
\hline 果核纵径 Longitudinal diameter of stone (mm) & 7.35 & 2.11 & 3.38 & 3.71 & 4.59 & 1.02 & 2.96 & 0.56 \\
\hline 果核横径 Stone diameter (mm) & 6.17 & 4.13 & 3.54 & 4.73 & 6.19 & 2.86 & 4.29 & 0.58 \\
\hline 花序小花数 Floret number of inflorescence & 12.08 & 34.40 & 27.70 & 26.32 & 11.82 & 0.06 & 20.06 & 0.51 \\
\hline 平均值 Mean value & 14.61 & 20.77 & 22.06 & 20.89 & 19.92 & 14.80 & 19.69 & 0.56 \\
\hline
\end{tabular}


异系数相对低海拔较小, 表型变异较低。

为了使各表型性状间具有可比性, 用 $R_{i}{ }^{\prime}$ 来衡量 居群内的极端变异程度。 $R_{i}{ }^{\prime}$ 最大的是托叶形状 $(0.74)$, 最小的是果柄粗和叶片颜色 $(0.41)$, 与变异系数的 变化趋势并不完全相同, 说明居群中各性状的变异 程度并不稳定。

\section{2 不同居群表型性状差异及表型分化}

表型分化系数表示居群间方差分量占遗传总 变异(居群间和居群内方差分量之和)的百分比。结
果表明, 各性状居群内的方差分量均大于居群间的 方差分量(表3)。居群内的平均方差分量为 $85.26 \%$, 居群间的平均方差分量为 $14.74 \%$, 各性状的表型分 化系数变异幅度为 $0.16-32.67 \%$, 其中较大的依次 为单果重 $(32.67 \%)$ 、叶长 $(27.67 \%)$ 、果实纵径 $(24.31 \%)$, 较小的为托叶形状 $(0.16 \%)$ 、果实硬度 $(0.73 \%)$ 、叶柄长 $(1.99 \%)$ 。33个表型性状居群间的 平均分化系数为 $13.90 \%$, 而居群内为 $86.10 \%$, 居群 内的多样性远远大于居群间, 说明居群内的变异是

表3 准噶尔山楂表型性状的方差分析

Table 3 Variance analysis of phenotypic characteristics of Crataegus songorica

\begin{tabular}{|c|c|c|c|c|c|c|c|}
\hline \multirow[t]{2}{*}{ 性状 Traits } & \multicolumn{2}{|l|}{ 均方 Mean square } & \multirow[t]{2}{*}{$\mathrm{F}$} & \multirow[t]{2}{*}{ Sig } & \multicolumn{2}{|c|}{ 方差分量 Variance components } & \multirow{2}{*}{$\begin{array}{l}\text { 表型分 } \\
\text {-化系数 } \\
V_{S T}(\%)\end{array}$} \\
\hline & $\begin{array}{l}\text { 居群内 } \\
\text { Within population }\end{array}$ & $\begin{array}{l}\text { 居群间 } \\
\text { Among populations }\end{array}$ & & & $\begin{array}{l}\text { 居群内 } \\
\text { Within population }\end{array}$ & $\begin{array}{l}\text { 居群间 } \\
\text { Among populations }\end{array}$ & \\
\hline 一年生枝长 Annual branch length (mm) & $1,851.668$ & $1,475.734$ & 0.797 & 0.530 & $1,815.1961$ & 251.5190 & 12.17 \\
\hline 一年生枝粗 Annual branch diameter (mm) & 0.388 & 0.630 & 1.624 & 0.176 & 0.3944 & 0.0421 & 9.64 \\
\hline 新梢长 New branch length (mm) & $3,494.973$ & $5,356.658$ & 1.533 & 0.200 & $3,537.9271$ & 680.9977 & 16.14 \\
\hline 单果重 Fruit weight (g) & 0.026 & 0.180 & 6.936 & 0.000 & 0.0323 & 0.0157 & 32.67 \\
\hline 果实纵径 Fruit longitudinal diameter (mm) & 0.374 & 2.091 & 5.590 & 0.000 & 0.4447 & 0.1428 & 24.31 \\
\hline 果实横径 Fruit diameter (mm) & 0.770 & 3.012 & 3.914 & 0.006 & 0.8587 & 0.2540 & 22.82 \\
\hline 果柄长 Fruit stalk length (mm) & 2.534 & 1.831 & 0.723 & 0.579 & 2.4755 & 0.2410 & 8.87 \\
\hline 果柄粗 Fruit stalk thickness (mm) & 0.006 & 0.018 & 3.041 & 0.021 & 0.0065 & 0.0021 & 24.15 \\
\hline 坐果数 Fruit setting number & 0.615 & 1.294 & 2.104 & 0.087 & 0.6379 & 0.1156 & 15.34 \\
\hline 果实硬度 Fruit hardness (kg/cm²) & 0.110 & 0.010 & 0.091 & 0.985 & 0.1046 & 0.0008 & 0.73 \\
\hline 可固性 Soluble solids (\%) & 5.589 & 18.268 & 3.269 & 0.015 & 6.0793 & 1.2828 & 17.42 \\
\hline 果实形状 Fruit shape & 0.799 & 0.62 & 0.776 & 0.544 & 0.7826 & 0.0464 & 5.60 \\
\hline 果皮颜色 Peel color & 0.785 & 1.904 & 2.425 & 0.054 & 0.8253 & 0.1241 & 13.07 \\
\hline 果肉颜色 Flesh color & 0.388 & 0.713 & 1.835 & 0.129 & 0.3984 & 0.0486 & 10.88 \\
\hline 果实风味 Fruit flavor & 1.266 & 1.261 & 0.997 & 0.414 & 1.2517 & 0.0884 & 6.60 \\
\hline 叶厚 Leaf thickness (mm) & 0.002 & 0.003 & 1.265 & 0.290 & 0.0023 & 0.0005 & 16.85 \\
\hline 叶面积 Leaf area $\left(\mathrm{cm}^{2}\right)$ & 10.696 & 23.508 & 2.198 & 0.076 & 11.1369 & 2.9202 & 20.77 \\
\hline 叶宽 Leaf width (cm) & 0.246 & 0.557 & 2.262 & 0.069 & 0.2570 & 0.0525 & 16.95 \\
\hline 叶长 Leaf length (cm) & 0.333 & 0.900 & 2.705 & 0.035 & 0.3538 & 0.1353 & 27.67 \\
\hline 叶形指数 Leaf length/leaf width & 0.004 & 0.004 & 1.102 & 0.361 & 0.0035 & 0.0007 & 17.25 \\
\hline 叶柄长 Petiole length (mm) & 19.332 & 11.263 & 0.583 & 0.676 & 18.7708 & 0.3819 & 1.99 \\
\hline 叶柄粗 Petiole thickness (mm) & 0.037 & 0.023 & 0.614 & 0.654 & 0.0360 & 0.0015 & 4.11 \\
\hline 叶柄指数 Petiole length/petiole thickness & 38.335 & 8.692 & 0.227 & 0.923 & 36.6297 & 0.9423 & 2.51 \\
\hline 叶片颜色 Leaf color & 0.099 & 0.121 & 1.217 & 0.309 & 0.0990 & 0.0151 & 13.23 \\
\hline 叶基形态 Leaf base morphology & 0.405 & 1.033 & 2.552 & 0.045 & 0.4276 & 0.1204 & 21.97 \\
\hline 叶缘形态 Leaf margin morphology & 0.054 & 0.026 & 0.482 & 0.749 & 0.0518 & 0.0022 & 4.00 \\
\hline 叶面状态 Status of leaf surface & 0.077 & 0.177 & 2.296 & 0.066 & 0.0808 & 0.0091 & 10.08 \\
\hline 托叶形状 Stipule shape & 0.401 & 0.021 & 0.052 & 0.995 & 0.3803 & 0.0006 & 0.16 \\
\hline 果核数 Stone number & 0.005 & 0.004 & 0.823 & 0.514 & 0.0050 & 0.0008 & 13.69 \\
\hline 鲜核重 Fresh stone weight (g) & 0.001 & 0.002 & 1.947 & 0.110 & 0.0008 & 0.0001 & 10.85 \\
\hline $\begin{array}{l}\text { 果核纵径 Longitudinal } \\
\text { diameter of stone (mm) }\end{array}$ & 0.068 & 0.264 & 3.853 & 0.006 & 0.0762 & 0.0180 & 19.08 \\
\hline 果核横径 Stone diameter (mm) & 0.069 & 0.334 & 4.840 & 0.001 & 0.0797 & 0.0190 & 19.26 \\
\hline $\begin{array}{l}\text { 花序小花数 Floret number of inflores- } \\
\text { cence }\end{array}$ & 9.265 & 43.064 & 4.648 & 0.002 & 10.6336 & 2.2995 & 17.78 \\
\hline 平均值 Mean value & 164.840 & 210.734 & 2.101 & 0.292 & 165.0436 & 28.5406 & 13.90 \\
\hline
\end{tabular}


其表型变异的主要来源。

\section{3 不同居群的表型聚类分析}

对准噶尔山楂 5 个居群的表型性状采用 UPGMA法进行聚类分析, 结果如图1所示。从图1 可以看出, 以遗传距离 9.97 为尺度, 把 5 个准噶尔山 楂居群分为两组。第一组包含居群 $1 、 2 、 3 、 4$, 居 群 5 另为一组。居群 2 和 3 先聚为一类, 再和居群 4 和 1 聚类, 最后和居群 5 聚类。在遗传距离为 6.25 时, 居 群2、3、4首先聚为一类, 这 3 个居群海拔相差较近, 地理环境也较相似, 阳光充足, 比较适宜野山楂的 生长, 所以有大量的野山楂分布。由于居群 1 和 5 处 于野山楂分布范围的边缘地带, 其温度、水分、光 照都不是野山楂生长的最适环境条件, 但低海拔相 较高海拔而言, 环境因素有所好转, 较适于准噶尔 山楂的生长, 所以居群 1 先与居群 $2 、 3 、 4$ 聚为一类。 由聚类结果可知, 准噶尔山楂分布范围内地理环境 因素对其生长影响较大, 其表型性状随着环境因素 的变化表现出一定的规律, 这与前面分析表型变异 所得结论基本吻合。

\subsection{SSR标记多态性}

在221对SSR引物中共筛选出43对重复性好、多 态性丰富的引物, 对 5 个居群的 92 个样本扩增后共 产生739个位点, 每个引物扩增总条带数在 7-31之 间(表4), 各引物在居群内呈现多态性, 平均每个引 物扩增的DNA条带数为 17.19 条, 扩增片段大小在 50-450 bp之间; 其中669个位点具有多态性(表5), 多态性位点比率为 $90.53 \%$, 表明准噶尔山楂具有较 高的遗传多样性。居群间平均Nei's遗传多样性指数 为 0.2377 , Shannon多样性指数 $(I)$ 为 0.3712 , 居群内 多态性位点比率在13.40-89.31\%之间。Nei's

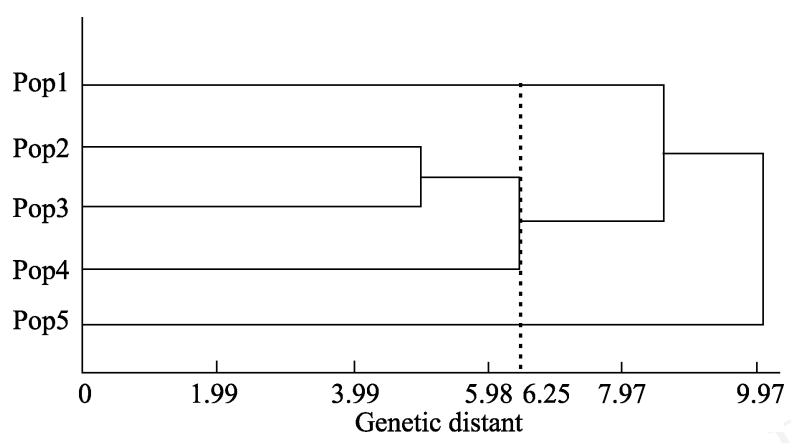

图1 基于形态特征的准噶尔山楂5个居群聚类图

Fig. 1 Dendrogram of five Crataegus songorica populations based on phenotypic characters
遗传多样性指数 $(H)$ 在0.0569-0.2635之间，平均为 0.1635; Shannon多样性指数 ( $I$ ) 在0.0830-0.4035之间， 平均为 0.2463 。所有居群中, 居群5 $(H=0.0569, I=$ $0.0830)$ 的遗传多样水平最低, 居群2 $(H=0.2635, I=$ 0.4035)的遗传多样水平最高。Nei's遗传多样性指 数、Shannon多样性指数与多态性位点比率所反映 的多样性趋势完全一致，均表明 5 个居群之间的 SSR遗传多样性有较大差异。遗传多样性指数是衡 量居群遗传多样性最常用的指标, 5 个居群遗传多 样性由高到低依次为: 居群 $2>$ 居群 $3>$ 居群 $4>$ 居群 $1>$ 居群 5 。

\section{5 居群的遗传分化}

遗传分化是反映居群结构的重要指标。准噶尔 山楂 5 个居群内基因多样度 $\left(H_{s}\right)$ 和总居群基因多样 度 $\left(H_{t}\right)$ 分别为 0.1635 和 0.2023 , 居群间遗传分化系数 $\left(G_{s t}\right)$ 为 0.1916 , 表明居群内变异为 $80.84 \%$, 居群间 变异为 $19.16 \%$ (表6), 说明准噶尔山楂的遗传变异主 要存在于居群内。基因流 $\left(N_{m}\right)$ 为 $2.1116>1$, 说明居 群间的基因流动性较大，居群间的分化比较小。 AMOVA分析表明(表7), 居群间的遗传变异为 $20.37 \%$, 远小于居群内的遗传变异, 说明变异主要 存在于居群内 $(79.63 \%)$, 此结果和POPGENE 1.32 分析结果相符合。

\section{6 准噶尔山楂居群间遗传距离和遗传一致度与 地理距离的相关性}

利用POPGENE 1.32软件计算出准噶尔山楂5 个不同居群的遗传距离 $(D)$ 及遗传一致度 $(I)$ (表 8$)$, 由表 8 可知, 居群 3 的样品与来自居群 2 、居群 4 的样 品遗传距离明显较小, 分别为 0.0211 和 0.0243 ; 相 应的遗传一致度较高, 分别为 0.9792 和 0.9760 , 这 说明居群 3 的样品与居群 2 和居群 4 的样品亲缘关系 较近。而居群 5 与居群 1 和居群 2 的遗传距离较大, 分 别为 0.1171 和 0.0993 , 相应的遗传一致度较低, 分 别为 0.8900 和 0.9057 , 说明居群 5 与居群 1 和居群 2 的 样品亲缘关系较远。各个居群间的遗传距离变异系 数为 $53.57 \%$, SPSS分析显示, 居群间的遗传距离与 地理距离间呈极显著相关 $(r=0.798, P<0.01)$ 。

\subsection{SSR分子标记的聚类分析}

基于NTSYS-pc 2.1分析92份准噶尔山楂SSR标 记获得数据矩阵, 并对其进行UPGMA聚类分析, 获得92个个体的遗传相似性聚类图(图2)。由图2可 知, 遗传相似性系数变化范围为 $0.46-0.95$, 个体间 
表4 SSR引物序列及其扩增结果

Table 4 Sequences of SSR primers and amplification results

\begin{tabular}{|c|c|c|c|c|c|c|c|}
\hline $\begin{array}{l}\text { 引物名称 } \\
\text { Primers }\end{array}$ & 正向引物 Forward primer (5'-3') & 反向引物 Reverse primer $\left(5^{\prime}-3^{\prime}\right)$ & $\begin{array}{l}\text { 退火 } \\
\text { 温度 } \\
\mathrm{TM} \\
\left({ }^{\circ} \mathrm{C}\right)\end{array}$ & $\begin{array}{l}\text { 扩增 } \\
\text { 总带 } \\
\text { 数 } \\
\text { Ampl- } \\
\text { ified } \\
\text { total } \\
\text { bands }\end{array}$ & $\begin{array}{l}\text { 多态 性 } \\
\text { 条带数 } \\
\text { Polym- } \\
\text { orphic } \\
\text { bands }\end{array}$ & $\begin{array}{l}\text { 多态性位 } \\
\text { 点比率 } \\
\text { Percentage } \\
\text { of polymo- } \\
\text { rphism } \\
\text { bands } \\
(\%)\end{array}$ & $\begin{array}{l}\text { 多态性信息 } \\
\text { 量 } \\
\text { Polymorphim } \\
\text { information } \\
\text { content } \\
(P I C)\end{array}$ \\
\hline XNDMa1 & CACGGTCATGAACTCCAT & TGGCAGATGGCTTAACTG & 46 & 10 & 10 & 100.00 & 0.82 \\
\hline XNDMa4 & GCCTTCACTGTCTGAGAG & CGGATGCTCCTGTTACAC & 55 & 19 & 18 & 94.74 & 0.91 \\
\hline XNDMa7 & CGTGTTCATTGTGTCCTTC & TTGCCTTCTCAAGACCATC & 61 & 14 & 11 & 78.57 & 0.9 \\
\hline XNDMa10 & CACTTCAGAGCCGCATTA & GAACAACCACGACCTTCT & 58 & 12 & 8 & 66.67 & 0.91 \\
\hline XNDMa11 & CTTCAGAGCCGCATTAGG & GAACAACCACGACCTTCT & 59 & 18 & 12 & 66.67 & 0.93 \\
\hline XNDMa14 & GCCGAACTACCGTTACCT & GCCGAAGTTGTAGATGTCC & 60 & 17 & 14 & 82.35 & 0.92 \\
\hline XNDMa15 & CTGACGACGACGATGAAG & CTGACGACGACGATGAAG & 52 & 23 & 21 & 91.30 & 0.94 \\
\hline XNDPy03 & СССТСССТСТТТСТСТТСТ & AGTTGGACATTGCGATGG & 47 & 16 & 14 & 88.00 & 0.92 \\
\hline XNDPy07 & CGATACAACAGAGAATTGAGTC & AAGAACCAGATGGCACAC & 46 & 16 & 16 & 100 & 0.91 \\
\hline XNDPy09 & CTTACCTAACAGGACTCAATG & GAGGATGGCAGCAATCTT & 48 & 10 & 9 & 90.00 & 0.86 \\
\hline XNDPy11 & AACAGGAAGAGGAGATGGT & CAATGAAAGCGGGAAACTG & 47 & 18 & 17 & 94.44 & 0.92 \\
\hline XNDPy 13 & CGAAGTTTACATAGGGTTCTCT & TGGGACACTCCAGCATGA & 54 & 17 & 16 & 94.11 & 0.9 \\
\hline XNDPy14 & CGCTCACTCCTCAGAAGT & TCGCCTCGTCCATTTGTA & 55 & 7 & 5 & 71.43 & 0.91 \\
\hline XNDPy 15 & AAAGTAAAGGCGGCAAATG & TCTAGGGTGCGTTTGTTG & 47 & 12 & 12 & 100.00 & 0.9 \\
\hline XNDPy16 & CTTCAAGTAGCCAACTATCAG & TGTTTCTGCAAACTGGTCTA & 52 & 11 & 10 & 90.91 & 0.88 \\
\hline XNDPy37 & CGGGTGTTGATTCTCTCT & GGTTGGACGAAGTTGATC & 52 & 13 & 13 & 100.00 & 0.88 \\
\hline XNDPy38 & GCAGCAGGAAACACAGAA & TTGGCGGTCATTGATAGTAA & 57 & 24 & 23 & 95.83 & 0.92 \\
\hline XNDPy40 & СССТTССТСАACTAACAGT & GGATAAGCGGTTCTGTAGA & 60 & 14 & 14 & 100.00 & 0.89 \\
\hline ZFRIt066 & TGGCTTTAAACGGTTATGCTG & TGAGGAGGGAGGGAATACAA & 46 & 17 & 17 & 100.00 & 0.93 \\
\hline ZFRIt067 & GCAAGACCCTTATGCCAACT & TGAGGCCTAACTGCTTCGAC & 62 & 15 & 15 & 100.00 & 0.9 \\
\hline ZFRIt084 & GCTGTTGAGCTAGGCAGGTT & CCCGAGTCCTCACCAAGTAA & 62 & 13 & 12 & 92.31 & 0.9 \\
\hline ZFRIt097 & ACTGTTTCCAGCAGGCTTGT & GAAGATTGCCCCACAGAAAA & 51 & 14 & 14 & 100.00 & 0.9 \\
\hline PES05 & ATGGTGGGTTGGCAGAG & GGTTGGAGCAGATGGT & 48 & 15 & 12 & 80.00 & 0.92 \\
\hline PES06 & CCCCAGAAACCCTAACC & AAGAGCGATGACACCACC & 51 & 22 & 19 & 86.36 & 0.94 \\
\hline ВРРСТ028 & TCAAGTTAGCTGAGGATCGC & GAGCTTGCCTATGAGAAGACC & 54 & 19 & 17 & 89.47 & 0.92 \\
\hline CH02h11a & CGTGGCATGCCTATCATTTG & CTGTTTGAACCGCTTCCTTC & 56 & 19 & 17 & 89.47 & 0.93 \\
\hline $\mathrm{CH} 02 \mathrm{~b} 10$ & CAAGGAAATCATCAAAGATTCAAG & CAAGTGGCTTCGGATAGTTG & 53 & 20 & 20 & 100.00 & 0.92 \\
\hline $\mathrm{CH} 05 \mathrm{~d} 03$ & TACCTGAAAGAGGAAGCCCT & TCATTCСТTCTCACATCCACT & 59 & 14 & 10 & 71.43 & 0.91 \\
\hline $\mathrm{CH} 05 \mathrm{e} 06$ & ACACGCACAGAGACAGAGACAT & GTTGAATAGCATCCCAAATGGT & 50 & 18 & 17 & 94.44 & 0.92 \\
\hline $\mathrm{HI} 02 \mathrm{c} 07$ & AGAGCTACGGGGATCCAAAT & GTTTAAGCATCCCGATTGAAA & 54 & 20 & 18 & 90.00 & 0.92 \\
\hline MS14h03 & CGCTCACCTCGTAGACGT & ATGCAATGGCTAAGCATA & 48 & 15 & 13 & 86.67 & 0.89 \\
\hline $\mathrm{CH} 03 \mathrm{a} 09$ & GCCAGGTGTGACTCCTTCTC & CTGCAGCTGCTGAAACTGG & 50 & 31 & 28 & 90.32 & 0.95 \\
\hline $\mathrm{CH} 02 \mathrm{a} 04$ & GAAACAGGCGCCATTATTTG & AAAGGAGACGTTGCAAGTGG & 58 & 15 & 12 & 80.00 & 0.9 \\
\hline $\mathrm{CH} 01 \mathrm{f} 03 \mathrm{~b}$ & GAGAAGCAAATGCAAAACCC & CCCGGCTCCTATTCTAC & 52 & 31 & 29 & 93.55 & 0.94 \\
\hline $\mathrm{CH} 02 \mathrm{a} 08$ & GAGGAGCTGAAGCAGCAGAG & ATGCCAACAAAAGCATAGCC & 60 & 14 & 12 & 85.71 & 0.91 \\
\hline $\mathrm{CH} 05 \mathrm{a} 04$ & GAAGCGAATTTTGCACGAAT & GCTTTTGTTTCATTGAATCCCC & 58 & 14 & 14 & 100.00 & 0.92 \\
\hline $\mathrm{CH} 01 \mathrm{~h} 01$ & GAAAGACTTGCAGTGGGAGC & GGAGTGGGTTTGAGAAGGTT & 59 & 22 & 21 & 95.45 & 0.93 \\
\hline CN851079 & ACCGCCACAACCACAATC & CTCGGGCAAGCGAAGAAT & 56 & 23 & 21 & 91.30 & 0.91 \\
\hline CN848770 & СTTATTCCTCCACTCCGATTC & AAACAGCCAAACCCAGCA & 54 & 15 & 14 & 93.33 & 0.87 \\
\hline CN581002 & TGGAGGGAAAGGAGAAGC & AAGTGGCAGGCAGCAGTA & 49 & 26 & 25 & 96.15 & 0.95 \\
\hline CV986977 & CTCAAACCCAAACCCTCC & TCTCCTGACCCACGAAAA & 55 & 22 & 21 & 95.45 & 0.89 \\
\hline CV882996 & СТTCTCCACTAACGCACCA & CCATTCTCAACCAGCACC & 53 & 20 & 18 & 90.00 & 0.92 \\
\hline CV794040 & CGTGGTTCCTGGTTGTGA & AAAGCAGTTGCCTCCCTC & 50 & 14 & 14 & 100.00 & 0.87 \\
\hline 合计 Total & & & & 739 & 673 & & \\
\hline 平均 Mean & & & & 17.19 & 15.65 & 90.60 & 0.91 \\
\hline
\end{tabular}


表5 准噶尔山楂居群的遗传多样性

Table 5 Genetic diversity of populations of Crataegus songorica

\begin{tabular}{|c|c|c|c|c|c|c|}
\hline $\begin{array}{l}\text { 居群 } \\
\text { Population }\end{array}$ & $\begin{array}{l}\text { 多态性位点数 } \\
\text { Polymorphism } \\
\text { locus number }\end{array}$ & $\begin{array}{l}\text { 多态性位点比率 } \\
\text { Percentage of poly- } \\
\text { morphism loci }(\%)\end{array}$ & $\begin{array}{l}\text { 观测等位基因 } \\
\text { Observed number of } \\
\text { alleles }\left(N_{a}\right)\end{array}$ & $\begin{array}{l}\text { 有效等位基因 }\left(N_{e}\right) \\
\text { Effective number of } \\
\text { alleles }\end{array}$ & $\begin{array}{l}\text { Nei's 基因多样性指 } \\
\text { 数 } \\
\text { Nei's gene diversity } \\
\text { index }(H)\end{array}$ & $\begin{array}{l}\text { Shannon多样性指数 } \\
\text { Shannon's diversity } \\
\text { index }(I)\end{array}$ \\
\hline Pop1 & 257 & 34.78 & $1.3837 \pm 0.4756$ & $1.2386 \pm 0.3538$ & $0.1375 \pm 0.1895$ & $0.2050 \pm 0.2720$ \\
\hline Pop2 & 660 & 89.31 & $1.9025 \pm 0.2938$ & $1.4342 \pm 0.3325$ & $0.2635 \pm 0.1722$ & $0.4035 \pm 0.2350$ \\
\hline Pop3 & 427 & 57.78 & $1.6061 \pm 0.4824$ & $1.3285 \pm 0.3655$ & $0.1938 \pm 0.1960$ & $0.2928 \pm 0.2786$ \\
\hline Pop4 & 327 & 44.25 & $1.4766 \pm 0.4908$ & $1.2883 \pm 0.3738$ & $0.1658 \pm 0.1996$ & $0.2473 \pm 0.2841$ \\
\hline Pop5 & 99 & 13.40 & $1.1372 \pm 0.3444$ & $1.0971 \pm 0.2435$ & $0.0569 \pm 0.1427$ & $0.0830 \pm 0.2082$ \\
\hline 平均 Mean & 354 & 47.90 & $1.5012 \pm 0.4174$ & $1.2773 \pm 0.3338$ & $0.1635 \pm 0.1780$ & $0.2463 \pm 0.2556$ \\
\hline $\begin{array}{l}\text { 物种水平 } \\
\text { Species level }\end{array}$ & 669 & 90.53 & $1.9136 \pm 0.2781$ & $1.3843 \pm 0.3302$ & $0.2377 \pm 0.1695$ & $0.3712 \pm 0.2301$ \\
\hline
\end{tabular}

表6 准噶尔山楂居群内和居群间基因的 $\boldsymbol{G}_{\mathrm{st}}$ 分析

Table 6 The $G_{s t}$ analysis of genetic differentiation among Crataegus songorica populations

\begin{tabular}{llll}
\hline & $\begin{array}{l}\text { 总居群基因多样度 } \\
\text { Total gene diversity } \\
\text { index }\left(H_{t}\right)\end{array}$ & $\begin{array}{l}\text { 居群内基因多样度 } \\
\text { Gene diversity within population } \\
\left(H_{s}\right)\end{array}$ & $\begin{array}{l}\text { 遗传分化系数 } \\
\text { Index of genetic differentiation } \\
\left(G_{s t}\right)\end{array}$ \\
\hline $\begin{array}{l}\text { 平均 Average } \\
\text { 标准差 Standard deviation }\end{array}$ & 0.2023 & 0.1635 & 0.1916 \\
\hline
\end{tabular}

表7 居群间和居群内分子变异的方差分析

Table 7 Analysis of molecular variance(AMOVA) within and among populations

\begin{tabular}{llllll}
\hline $\begin{array}{l}\text { 变异来源 } \\
\text { Source of variation }\end{array}$ & $\begin{array}{l}\text { 自由度 } \\
\mathrm{df}\end{array}$ & $\begin{array}{l}\text { 平方和 } \\
\text { Sum of square }\end{array}$ & $\begin{array}{l}\text { 均方 } \\
\text { Mean square }\end{array}$ & $\begin{array}{l}\text { 方差分量 } \\
\text { Variance component }\end{array}$ & $\begin{array}{l}\text { 方差分量百分率 } \\
\text { Percentage of variance component }\end{array}$ \\
\hline $\begin{array}{l}\text { 居群间 } \\
\begin{array}{l}\text { Among populations } \\
\text { 居群内 }\end{array}\end{array}$ & 0.3890 & 0.0972 & 0.0185 & $20.37 \%$ \\
\begin{tabular}{l} 
Within population \\
\hline
\end{tabular} & 91 & 6.7171 & 0.0772 & 0.0723 & $79.63 \%$ \\
\hline
\end{tabular}

表8 准噶尔山楂5个居群间的遗传一致度(对角线上)与遗传距离(对角线下)

Table 8 Nei's genetic identity (above the diagonal) and genetic distance (below the diagonal) among five populations of Crataegus songorica

\begin{tabular}{llllll}
\hline & 居群1 Pop1 & 居群2 Pop2 & 居群3 Pop3 & 居群4 Pop4 & 居群5 Pop5 \\
\hline 居群1 Pop1 & $* * * *$ & 0.9641 & 0.9595 & 0.9510 & 0.8900 \\
居群2 Pop2 & 0.0366 & $* * * *$ & 0.9792 & 0.9678 & 0.9057 \\
居群3 Pop3 & 0.0414 & 0.0211 & $* * * *$ & 0.9760 & 0.9315 \\
居群4 Pop4 & 0.0503 & 0.0327 & 0.0243 & $* * * *$ & 0.9247 \\
居群5 Pop5 & 0.1171 & 0.0993 & 0.0711 & 0.0785 & $* * * *$ \\
\hline
\end{tabular}

遗传相似性变化较大。在遗传相似性系数为 0.70 时, 可将供试材料分为三大类: 第一大类包含了本实 验所采样品的绝大多数, 说明样品 47 号和 19 号与 其他样品间遗传相似性较小, 亲缘关系较远; 在 遗传相似性系数为 0.79 时, 第一大类又可细分为 4 个亚类, 其中第一亚类中包含了 86 份材料。由此可 知, 准噶尔山楂的遗传距离较小, 亲缘关系较近,
大部分种质表现为同一居群聚在一起, 但部分种 质也存在不同居群聚在一起的现象。其中居群 5 的 89 号和 90 号 2 个体的亲缘关系最近, 其次是居群 3 的58号和 63 号。居群聚类结果显示出一定的地域相 关性, 地域分布较近和处于相似地理环境的居群 显示出更近的亲缘关系, 这与前面表型变异所得 结论吻合。 


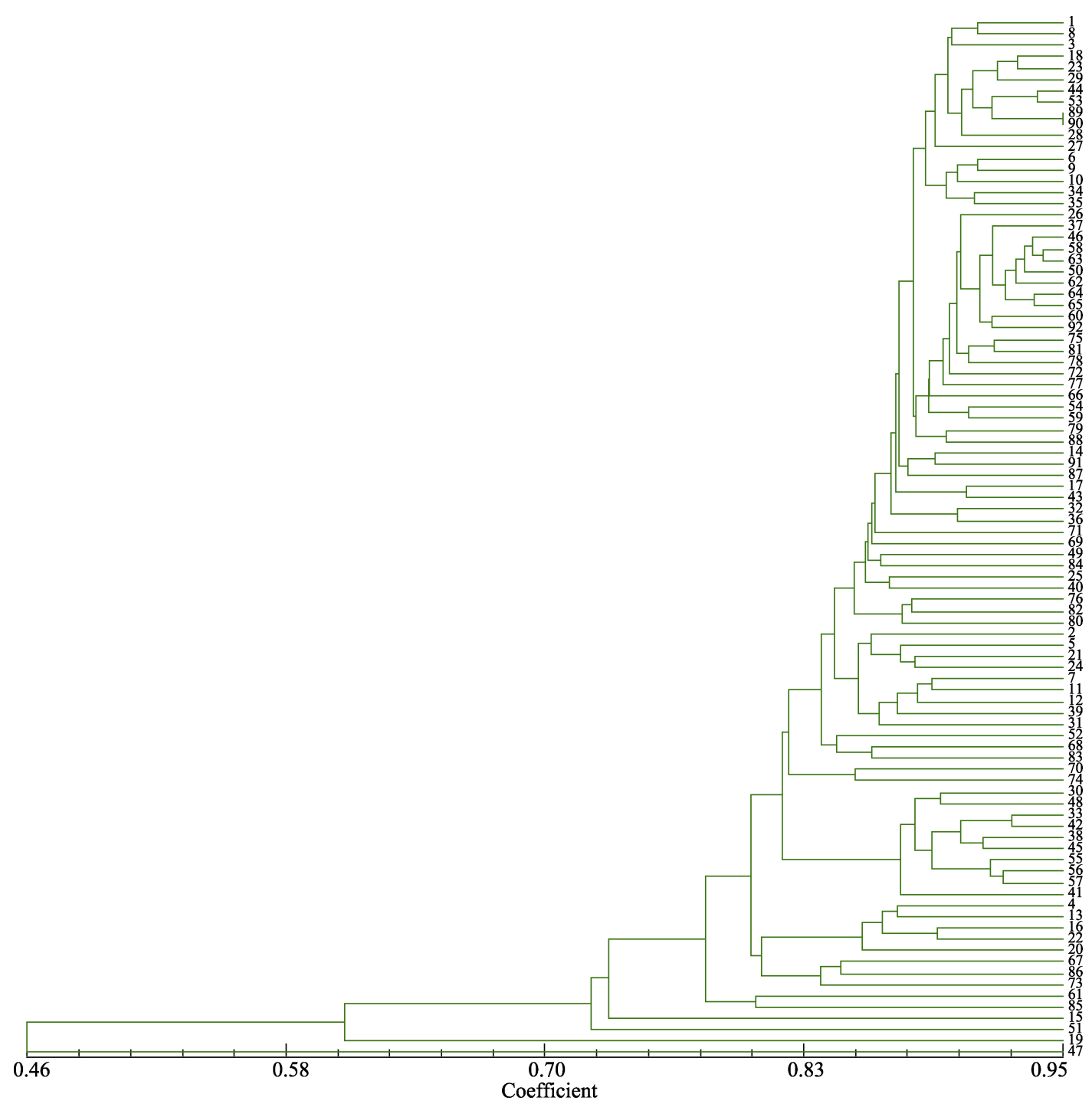

图2 依据UPGMA法构建的准噶尔山楂92个个体的聚类图

Fig. 2 Clustering dendrogram of 92 Crataegus songorica individuals based on UPGMA
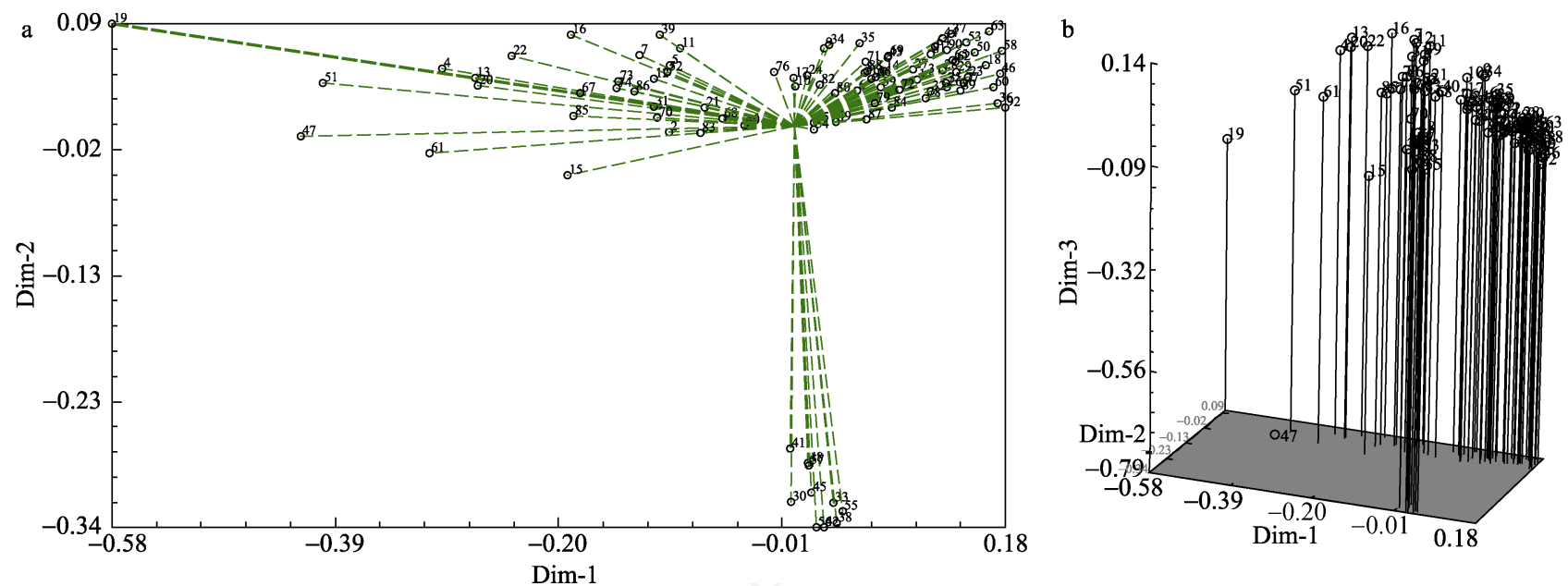

图392份准噶尔山楂资源SSR标记的主坐标分析图。(a)平面散点图; (b)三维空间图。

Fig. 3 Principal coordinate analysis for 92 Crataegus songorica resources. (a) Planar graph; (b) Three-dimensional graph. 


\subsection{SSR分子标记的主坐标分析}

运用NTSYS-pc 2.1将92份材料进行主坐标分 析, 建立起平面散点图(图3a)和三维空间图(图3b), 由图3可知, 第 $1 、 2 、 3$ 主成分分别解释了 $12.51 \%$ 、 $7.17 \% 、 5.91 \%$ 的样本间相关性, 92份样品被分为 2 个 大组, 其中 10 份野山楂资源亲缘关系较近, 被划分 为第一大组(I), 余下的 82 份资源被分为第二大组 (II)。根据供试材料在主坐标图中的分布位置, 第二 大组又可分为 7 亚组: 19 号为第一亚组, $47 、 51$ 号为 第二亚组, 4、13、20、22、16号为第三亚组, 61 号 为第四亚组, $15 、 67 、 85$ 号为第五亚组, $2 、 5 、 7 、$ $11 、 12 、 21 、 31 、 39 、 40 、 52 、 68 、 70 、 73 、 74$ 、 $83 、 86$ 号为第六亚组, 其余为第七亚组。与UPGMA 的聚类结果相比, 两种分析方法在准噶尔山楂亲缘 关系的研究中存在部分差异: 如 25 号和 54 号在 UPGMA中未聚在一起, 但在主坐标中却聚在一起。 可见, 准噶尔山楂的基因型复杂。比较两种聚类结 果可知, 它们的群组划分趋向一致, 但个体间的聚 类结果并不相同, 主坐标可更清晰地反映92份准喝 尔山楂之间的遗传分化和亲缘关系的远近。

\section{3 讨论}

\section{1 不同居群的遗传多样性和遗传结构}

种质资源的遗传多样性可以通过表型性状分 析和分子标记进行评价，不同种质资源的表型性状 分析和遗传多样性研究也是育种研究的重要基础 (Campbell, 2009; 胡标林等, 2012)。近年来, 野生种 质资源的遗传多样性已成为研究的热点问题。由于 人为因素, 野山楂资源破坏严重, 并且大多零星分 布或多以种质资源围的形式存在。实地调查发现, 准噶尔山楂在大西沟分布较多且较集中, 具有很好 的代表性。表型变异是遗传变异的重要线索。5 个 居群的 33 个表型性状的变异系数、方差、分化系数 之间均存在较大的差异, 变异程度也各不相同, 说 明各居群的各个表型性状之间存在着较丰富的遗 传变异。测量的 33 个表型性状的平均变异系数为 $13.75 \%$, 变异幅度为 $2.96-71.32 \%$, 显著高于新疆野 生樱桃李(刘崇琪等, 2008) ( $C V:$ : 2.75-9.13\%)和新疆 野杏(曹倩等, 2016) (CV: 0-53.99\%)。说明准噶尔山 楂对生境的适应范围较广, 环境的形态可塑性较大。

山楂与苹果、梨、杏等同为蓄薇科, 属于近缘 种植物，而物种间的DNA序列具有的同源性，使得
同科属植物可以通用一些SSR引物。如张叶等(2008) 利用通用引物分析了山楂属植物的遗传关系, 韩志 校等(2014)用苹果SSR引物分析了不同山楂品种。 本研究用篎选的43对SSR引物对92份准噶尔山楂材 料进行 SSR-PCR 标记, 其遗传多样性 $(P P L=$ $90.53 \% 、 I=0.3712 、 H=0.2377)$ 水平高于用SSR标 记对山楂的研究 $(P P L=86.42 \%)$ (韩志校等, 2014) 和用 ISSR 引物标记的新疆野生山楂材料 $(P P L=$ $94.4 \% 、 I=0.2331 、 H=0.1507$ ) (刘欢等, 2016), 稍 低于利用SSR标记对新疆普通杏的研究结果 $(I=$ $0.43, H=0.299$ ) (何天明等, 2006)。由此可知，与栽 培山楂品种相比, 新疆野山楂资源具有丰富的多态 性; 而霍城大西沟的准噶尔山楂多态性更为丰富, 与刘欢等(2016)的研究结果相一致。这可能与其分 布有关: 不同海拔居群间生态因子的差异, 导致不 同居群产生不同的表型; 不同的表型和基因型相组 合, 导致大西沟居群间的遗传多样性水平增高。加 之在新疆其他区域分布的野山楂多为人工引种的 实生繁殖体, 而大西沟准噶尔山楂为自然生长的野 生资源，所以其多态性水平更高; 而且根据基因多 样性指数得到居群 $2 、 3$ 的遗传多样性水平明显高于 居群 $1 、 5$, 这符合地理分布范围是决定物种遗传多 样性的主要因素之一的论点。但总体来说, 新疆准 噶尔山楂的分布面积少于新疆杏, 这也是其遗传多 样性稍低于新疆杏的原因之一。

遗传结构是指遗传多样性在居群内和居群间 的分布及遗传分化(Meeus et al, 2012; Zia et al, $2014)$ 。本研究中 5 个居群的 $G_{s t}$ 为 0.1916 , 表明仅有 19.16\%的遗传变异来源于居群间, 而主要的遗传变 异来自居群内的个体间。Gonzalez-Martinez等(2002) 提出, 遗传分化系数 $\left(F_{s t}\right)$ 小于 0.25 时, 表明居群遗 传分化较低。本研究中方差分析结果显示 $F_{s t}=$ 0.2037, 居群间遗传分化较低, 与 $G_{s t}$ 的分析结果相 一致。

基因流是促进居群间遗传分化的主要因素之 一, 种子和花粉的扩散是植物居群间基因流的两种 主要形式。新疆准噶尔山楂生境片断化不严重, 且 山楂为异花授粉植物, 其基因流主要通过虫媒传 粉、人类及野生动物对其种子的取食和聍藏等方式 完成扩散。基因流大于 1 时能有效防止遗传漂变引 起的遗传分化(Opedal et al, 2016), 5 个采样地的基因 流为2.1116, 居群间的基因流动性较大, 居群间的分 
化较小, 很可能是较高的基因流阻止了大西沟准噶 尔山楂居群之间的遗传分化。

\section{2 不同居群准噶尔山楂的遗传距离及聚类分析}

植物居群的遗传变异与该物种的生境特征和 分布格局有关(Ramos et al, 2016)。以表型性状构建 的聚类树和SSR 分子标记获得的UPGMA聚类图在 居群间大体一致，但在各样本的遗传距离之间有差 异, 可能是因为表型性状受到其本身遗传组成和环 境因素的影响, 在居群间既具有一定的稳定性, 又 具有一定的变异性。并且准噶尔山楂 5 个居群在 33 个表型上的分化系数 $13.90 \%$ 低于基因分化系数 $19.16 \%$, 说明不同居群之间的遗传多样性受到环境 因子的影响。居群间聚类结果显示: 居群 $2 、 3 、 4$ 在其分布区内变异丰富, 遗传多样性较高。而居群1 与 5 海拔跨度大、环境条件复杂, 居群 1 处于分布区 的最低处, 受到的人为干扰较多, 加上放牧的破坏, 使其分布数量减少; 居群5分布在大西沟整个野山 楂分布的边缘地带, 在海拔 $1,500 \mathrm{~m}$ 时只是零星分 布, 受相似环境的影响, 居群内存在很大程度的近 亲繁殖, 使得遗传变异幅度较小。加之所处的地理 区域的光照水分并不是其生长的最适宜环境, 所以 居群1、5与其他居群的相似性系数较小。准噶尔山 楂平均遗传距离为 0.0572 , 样本间遗传距离和地理 距离之间具有显著的相关性 $(r=0.798)$, 亲缘关系的 远近与地理位置远近的格局大致吻合, 地理位置较近 的居群, 其遗传距离也相对较小。

\section{3 保护策略}

本研究发现准噶尔山楂资源遗传多样性丰富, 生境的破坏可能是其居群急剧衰退的主要原因, 所 以应最大限度地保护其遗传变异基因库。本研究中 居群 2 和 3 的遗传多样性水平最高, 所以应对其进行 重点保护。建议尽可能就地保护准噶尔山楂的天然居 群生境, 禁止乱砍滥挖。

根据准噶尔山楂丰富的表型变异度及其在居 群内和居群间变异的分布情况, 可知其具有十分广 阔的改良前景。因此就大西沟准噶尔山楂的保护和 研究提出以下建议: (1)加强大西沟现有天然林的保 护，禁止人畜破坏。(2)就地保护和异地保存相结合, 营造野山楂种质资源收集圃。目前, 新疆已有的一 些种质资源圃中已收集有少量野山楂资源, 如新疆 伊犁地区新源县野生果树资源围、新疆农科院轮台 国家果树资源圃、新疆乌鲁木齐市植物园等。但对
于野山楂种质的异地保护工作依旧处于收集保存 阶段，而且没有采用多基因库采样法，建议今后多 采集具有表型特征差异及通过分子标记后鉴定的 不同类型，收集尽可能多的遗传多样性。重点收集 不同种源地、不同居群及垂直分布的边缘区域的样 本，使其处于一个较开放的授粉环境，促进基因交 流, 复壮物种生活力。(3)虽然居群间各性状变异较 小, 但在进行野山楂遗传改良时, 可将对居群的改 良和对居群内个体的改良结合起来, 同时利用居群 内和居群间的遗传变异, 有助于提高野山楂的环境 适应能力。这对野山楂种质资源遗传多样性的进一 步研究、遗传改良及其种质资源的保护和利用具有 重要的意义。

致谢: 本文的调查工作得到了新疆伊犁州林业科学 研究院主管部门及相关工作人员的大力支持和协 助，特此感谢！同时特别感谢《生物多样性》的审 稿专家所提的宝贵意见，以及责编极度细致的修改 与校正, 使本文的写作更加精准与严谨, 向他们致 以谢意!

\section{参考文献:}

An MM, Wang YT, Song Y, Ji XH, Liu C, Wang N, Wu YS, Liu W, Cao YF, Feng SQ, Chen XS (2014) Genetic diversity of fruit phenotypic traits of wild Pyrus ussuriensis Maxim. Scientia Agricultura Sinica, 47, 3034-3043. (in Chinese with English abstract) [安萌萌, 王艳廷, 宋杨, 冀晓昊, 刘 畅, 王楠, 吴玉森, 刘文, 曹玉芬, 冯守千, 陈学森 (2014) 野生秋子梨(Pyrus ussuriensis Maxim)果实性状的 遗传多样性. 中国农业科学, 47, 3034-3043.]

Bao WQ, Wuyun TN, Wang L, Zhao H, Du HY (2016) Genetic diversity and population structure of wild apricot in Xinjiang revealed by SSR markers. Acta Botanica Boreali-Occidentalia Sinica, 36, 1757-1763. (in Chinese with English abstract) [包文泉, 乌云塔娜, 王琳, 赵罕, 杜红岩 (2016) 基于SSR标记的新疆野杏群体遗传多样性及遗传 结构. 西北植物学报, 36, 1757-1763.]

Campbell DR (2009) Using phenotypic manipulations to study multivariate selection of floral trait associations. Annals of Botany, 103, 1557-1566.

Cao Q, Liao K, Liu J, Xu GX, Sun Q, Si HZ, Yang XF (2016) Study on the Daxigou wild apricot fruit phenotypic diversity in Huocheng County, Xinjiang. Xinjiang Agricultural Sciences, 53, 791-798. (in Chinese with English abstract) [曹 倩, 廖康, 刘娟, 徐桂香, 孙琪, 司洪章, 杨新峰 (2016) 新疆霍城县大西沟野杏果实表型多样性研究. 新疆农业 科学, 53, 791-798.] 
Dong Y, Zhang J, Ren YC, Han ZX (2013) Study on genetic diversity of natural population in Malus sieversii with microsatellite. Journal of Plant Genetic Resources, 14, 771-777. (in Chinese with English abstract) [董研, 张军, 任亚超, 韩志校 (2013) 中国新疆野苹果天然群体遗传 多样性SSR分析. 植物遗传资源学报, 14, 771-777.]

Ge S, Wang MX, Chen YW (1988) An analysis of population genetic structure of masson pine by isozyme technique. Scientia Silvae Sinicae, 24, 399-409. (in Chinese with English abstract) [葛颂, 王明庥, 陈岳武 (1988) 用同工酶研 究马尾松群体的遗传结构. 林业科学, 24, 399-409.]

Geng WJ, Liao K, Diao YQ, Xu Z, Sha H (2012) Analysis of genetic relationships among different populations of Prunus domestica L. based on SSR marker. Acta Horticulturae Sinica, 39(Suppl.), 2602. (in Chinese) [耿文娟, 廖康, フ永 强, 许正, 沙红 (2012) 野生欧洲李不同居群亲缘关系的 SSR分析. 园艺学报, 39(增刊), 2602.]

Gonzalez-Martinez SC, Alia R, Gil L (2002) Population genetic structure in a Mediterranean pine (Pinus pinaster Ait.): a comparison of allozyme markers and quantitative traits. Heredity, 89, 199-206.

Gu QH, Xiong BX, Chen J, Huang J, Zhu YT (2011) Application of microsatellite DNA markers in population genetics studies of freshwater gastropoda. Chinese Journal of Applied and Environmental Biology, 17, 280-286. (in Chinese with English abstract) [顾钱洪, 熊邦喜, 陈洁, 黄瑾, 朱玉 婷 (2011) 微卫星标记技术在淡水腹足类种群遗传学研 究中的应用. 应用与环境生物学报, 17, 280-286.]

Han ZX, Bi ZL, Lu FQ, Gao P, Zhang PF, Li JH, Zhang J (2014) Analysis of the relative relationship of different hawthorn cultivars by apple SSR primers. Hebei Journal of Forestry and Orchard Research, 29, 165-168. (in Chinese with English abstract) [韩志校, 毕振良, 陆风勤, 高朋, 张 朋飞, 李舰航, 张军 (2014) 利用苹果引物对不同山楂品 种的SSR分析. 河北林果研究, 29, 165-168.]

He TM (2006) Study on Genetic Diversity of Chinese Common Apricot (Prunus armeniaca) Germplasm and Origin of Purple Apricot (Prunus dasycarpa). PhD dissertation, Shandong Agricultural University, Tai'an, Shandong. (in Chinese with English abstract) [何天明 (2006) 中国普通杏(Prunus armeniaca) 种质资源遗传多样性及紫杏 (P. dasycarpa) 起源 研究. 博士学位论文, 山东农业大学, 山东泰安.]

Hu BL, Wan Y, Li X, Lei JG, Luo XD, Yan WG, Xie JK (2012) Analysis on genetic diversity of phenotypic traits in rice (Oryza sativa) core collection and its comprehensive assessment. Acta Agronomica Sinica, 38, 829-839. (in Chinese with English abstract) [胡标林, 万勇, 李霞, 雷建国, 罗向东, 严文贵, 谢建坤 (2012) 水稻核心种质表型性状 遗传多样性分析及综合评价. 作物学报, 38, 829-839.]

Huang CQ, Liu GD, Bai CJ, Wang WQ, Tang J, Yu DG (2012) A study on the morphological diversity of 475 accessions of Cynodon dactylon. Acta Prataculturae Sinica, 21(4), 33-42. (in Chinese with English abstract) [黄春琼, 刘国道, 白昌 军, 王文强, 唐军, 虞道耿 (2012) 475份狗牙根种质资源
形态多样性的研究. 草业学报, 21(4), 33-42.]

Liu CQ, Chen XS, Wang JZ, Chen XL, Wang HB, Tian CP, Wu CJ (2008) Studies on genetic diversity of phenotypic traits in wild myrobalan plum (Prunus cerasifera Ehrh.). Acta Horticulturae Sinica, 35, 1261-1268. (in Chinese with English abstract) [刘崇琪, 陈学森, 王金政, 陈晓流, 王海 波, 田长平, 吴传金 (2008) 新疆野生樱桃李果实部分表 型性状的遗传多样性分析. 园艺学报, 35, 1261-1268.]

Liu H, Liao K, Liu J, Zhao SR, Sun Q, Cao Q (2016) Analysis of genetic diversity and genetic relationship of wild hawthorn resources in Xinjiang by ISSR markers. Nonwood Forest Research, 34(2), 19-23. (in Chinese with English abstract) [刘欢，廖康，刘娟，赵世荣，孙琪，曹倩 (2016) 新疆野生山楂资源遗传多样性及亲缘关系的ISSR分析. 经济林研究, 34(2), 19-23.]

Liu H, Liao K, Sun Q, Cao Q, Peng XL, Yang XF, Si HZ (2015) A study on flower bud morphological differentiation of wild hawthorn in Xinjiang. Journal of Xinjiang Agricultural University, 38, 36-39. (in Chinese with English abstract) [刘欢, 廖康, 孙琪, 曹倩, 彭晓莉, 杨新峰, 司洪 章 (2015) 新疆野山楂花芽形态分化的研究. 新疆农业 大学学报, 38, 36-39.]

Liu H, Liao K, Sun Q, Yang XF, Si HZ, Cao Q (2014) Research on morphlogical characteristics of flower organ of wild hawthorn in Xinjiang. Journal of Xinjiang Agricultural University, 37, 293-297. (in Chinese with English abstract) [刘欢, 廖康, 孙琪, 杨新峰, 司洪章, 曹倩 (2014) 新疆3 种野生山楂花器官形态特征研究. 新疆农业大学学报, 37, 293-297.]

Lü DG, Li ZX (2006) Description Criterion and Data Standard for Hawthorn Germplasm Evaluation. China Agriculture Press, Beijing. (in Chinese) [吕德国, 李作轩 (2006) 山楂 种质资源描述规范和数据标准. 中国农业出版社, 北京.]

Lü HY, Zhou LL, Li J, Zhang J (2011) The studies on extracting technology of pigments from Crataegus songorica. Anhui Agricultural Science Bulletin, 17(9), 25-27. (in Chinese with English abstract) [吕海英, 周露露, 李进, 张瑾 (2011) 准噶尔山楂果实色素提取工艺研究. 安徽农学通 报, 17(9), 25-27.]

Meeus S, Honnay O, Jacquemyn H (2012) Strong differences in genetic structure across disjunct, edge, and core populations of the distylous forest herb Pulmonaria officinalis (Boraginaceae). American Journal of Botany, 99, 18091818.

Opedal H, Falahati-Anbaran M, Albertsen E, Armbruster WS, Perez-Barrales R, Stenien HK, Pelabon C (2017) Euglossine bees mediate only limited long-distance gene flow in a tropical vine. New Phytologist, 213, 1898-1908.

Ramos R, Song G, Navarro J, Zhang R, Symes CT, Forero MG, Lei $F$ (2016) Population genetic structure and long-distance dispersal of a recently expanding migratory bird. Molecular Phylogenetics and Evolution, 99, 194-203.

Wang K, Liu FZ, Zhao JC, Gong X, Gao Y, Liu LJ (2008) Study on partial phenotypic diversity of apple germplasm 
resources. China Fruits, (5), 20-25. (in Chinese) [王昆, 刘 凤之, 赵进春, 龚欣, 高源, 刘立军 (2008) 苹果种质资 源部分表型多样性研究. 中国果树, (5), 20-25.]

Wang ZY, Dong YZ, Chen H, Wang RF (2011) Rapid DNA extraction method from Xinjiang Yili wild walnut for SSR-PCR. Northern Horticulture, (19), 100-103. (in Chinese with English abstract) [王肇延, 董玉芝, 陈虹, 王瑞 芬 (2011) 适用于新疆野核桃SSR-PCR的快速提取DNA 的方法. 北方园艺, (19), 100-103.]

Yin LK (2006) Rare and Endangered Endemic Higher Plants in Xinjiang of China. Xinjiang Science and Technology Publishing House, Urumqi. (in Chinese) [尹林克 (2006) 新疆 珍稀濒危特有高等植物. 新疆科学技术出版社, 乌鲁木 齐.]

Yu WL, Zhang B (2012) A study on morphological variation of pods and seeds of Medicago falcata collected from Zhaosu, Xinjiang. Acta Prataculturae Sinica, 21, 249-255. (in Chinese with English abstract) [于万里, 张博 (2012) 新疆昭
苏野生黄花苜宿果实形态变异研究. 草业学报, 21 , 249-255.]

Zhang Y, Dai HY, Zhang QJ, Li H, Zhang ZH (2008) Assessment of genetic relationship in Crataegus genus by the apple SSR primers. Journal of Fruit Science, 25, 521-525. (in Chinese with English abstract) [张叶, 代红艳, 张琪静, 李 贺, 张志宏 (2008) 利用苹果SSR引物分析山楂属植物遗 传关系. 果树学报, 25, 521-525.]

Zhao HZ, Feng BT (1996) China Fruit Plant Monograph: Hawthorn (Crataegus) Flora. China Forestry Publishing House, Beijing. (in Chinese) [赵焕谆, 丰宝田 (1996) 中 国果树志・山楂卷. 中国林业出版社, 北京.]

Zia ZU, Sadaqat HA, Tahir MH, Sadia B, Bushman BS, Hole D, Michaels L, Malik W (2014) Estimation of genetic diversity using SSR markers in sunflower. Genetika, 50, 570-580.

(责任编委: 周世良 责任编辑: 时意专) 